\title{
Local Wisdom for Sustainable Rural Tourism: The Case Study of North Tugu Village, West Java Indonesia
}

\author{
Fifi Nofiyanti ${ }^{1, *}$, Deivy Zulyanti Nasution ${ }^{1}$, Dian Octarina $^{1}$, R.M.W. Agie Pradhipta ${ }^{1}$ \\ ${ }^{1}$ STP Trisakti, IKPN Bintaro, Tanah Kusir, 12330, Jakarta, Indonesia
}

\begin{abstract}
This study aims to discuss local wisdom for the development of sustainable rural tourism in Bogor, West Java, Indonesia. Culture that was grown in some area and society can't be lost because of the development of era. This case study was conducted to find out the local wisdom in Tugu Utara Village, so that it can be used as a tourist attraction. This is expected to be developed into a sustainable tourism village in Bogor. The methodology in this research is qualitative with ethnography. This study found that: economic viability in the village is classified as an entrepreneurial community and tourism actors; local prosperity in the village including prosperous areas of mountainous natural resources, hills, and plantations (tea and coffee); visitor fulfillment; employment quality (villagers serve very friendly); social equity; local control (local culture is still developed in the village and has a characteristic "punten" culture that is courtesy); community wellbeing; cultural richness (culture in the village is still very applied, such as the use and speech of Sundanese language, applying the greeting "punten"); physical integrity (integrity and enthusiasm of young people to build a high village); biological diversity (diversity in villages such as); resource efficiency; environmental purity (nature presented is still beautiful, natural, and cool). The recipient application of this research study is the people of North Tugu Village, especially the tourism village managers.
\end{abstract}

\section{Introduction}

Local wisdom is part of the community culture which is applied from generation to generation. Culture that grows in a region and society should not be lost because of the times. The digital era is currently a trend for people to travel. However, due to the constraints of the Covid 19 pandemic in various countries, various industrial sectors declined and were forced to lockdown. The tourism industry has also experienced a decline. Judging from the temporary survey on several social media, people have complained of experiencing boredom. The tourism route in Bogor is seen by several people who enjoy the atmosphere of a tea garden on the side of the road, even though tourist destinations are not yet open to the public.

Profile of Tugu Utara Village, Bogor is located in Cisarua sub-district, Bogor Regency, West Java Province. Has regional potential in the form of tourist destinations (Cilember,

\footnotetext{
${ }^{*}$ Corresponding author: fifi.nofiyanti17@stptrisakti.ac.id
} 
Puncak, Batulayang, Cibulao coffee natural resources, Cisarua, and Paragliding destinations).

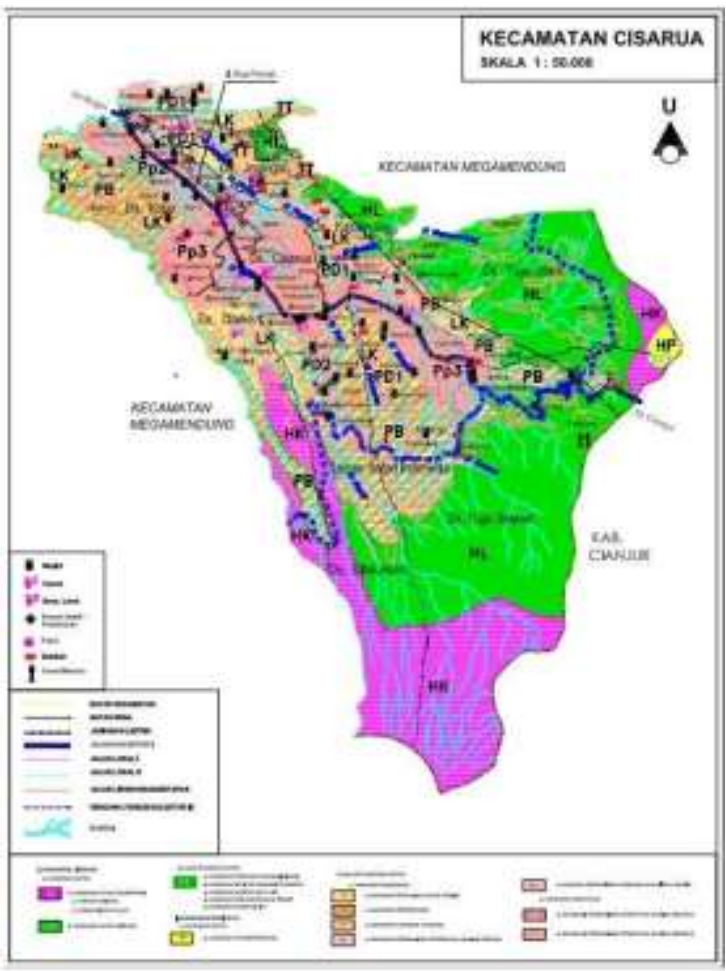

Source: [10]

Fig. 1. Map of Tugu Utara Village

The Tugu Utara area of Bogor is located in the highlands of the summit, having an altitude of less than $500 \mathrm{~m}$ above sea level. Tourism in the era of 4.0. more to do with photo tourism. Local wisdom in the village needs to be introduced, developed and applied to preserve culture.

Saving the Ciliwung River should have been done from the upstream area [6]. One obvious example is the environmental awareness actions carried out by the community in Cibulao Village, Tugu Utara Village, Cisarua District. The people of Cibulao Village are trying to open new perspectives by utilizing forest products without having to lose their function. The coffee commodity is an option as an agroforestry plant that helps people use forests from non-timber forest products.

From the result of [1], the local wisdom in South Borneo is varied both in their unique characteristics and also philosophical values, such as the mother language, proverbs, handicrafts in clothing, houses, and Aji stone, culinary, and their socio-economic activities.

Based on the preliminary information, the people in the village of North Tugu have tried to take initiatives for the development of their village and overcome the problems at the top of Bogor regarding environmental awareness. It is necessary to search for data and further empowerment actions to establish a helix in helping village communities. The village of Tugu Utara Bogor is an area of West Java which has local wisdom. The existence of local cultural traditions that grow in the area needs to be developed to achieve sustainable rural tourism.

This case study was conducted to determine the level of community needs, the suitability of rural tourism, and to find out existing local wisdom. It is hoped that this can be developed into sustainable tourism in the village of Tugu Utara Bogor. 


\section{Literature Review}

Local wisdom from a tourism perspective can be translated into a tourist attraction. By applying local wisdom, we can protect culture and the environment. Local wisdom can be in the form of traditions or customs, history, historical objects, traditional musical instruments, and others. The application of local wisdom in the tourism industry keeps the environment beautiful and maintains the integrity of the community in it.

Local wisdom is the attitudes, views, and abilities of a community in managing its spiritual and physical environment, which gives the community resilience and growth power in the area where the community is located [8]. In other words, local wisdom is a creative response to a geographic, political- historical and situational situation that is local in nature.

Developing a tourism village based on local wisdom is an activity that is not easy to do if it is not supported by all components of the community in the village. An example is the potential for local wisdom that exists, such as rice harvesting activities which are initiated using certain ceremonies, rituals of asking for rain and so on.

Local wisdom has six dimensions, namely: a) Local Knowledge. Dimensions every community has the ability to adapt to their environment because people have local knowledge in controlling nature. As well as public knowledge about climate change and a number of other natural phenomena; b) Local Value Dimensions. Every community has local rules or values regarding actions or behavior which are adhered to and mutually agreed upon by all its members but these values will change according to the progress of the community. The values of actions or behavior that exist in one group are not necessarily agreed upon or accepted in other groups of society, they are unique. Like the Dayak tribes with a tradition of tattoos and piercing in several parts of the body; c) Local Skills. Dimensions every society has the ability to survive (survival) to meet the needs of each family or it is called the substance economy. This is a way of maintaining human life that depends on nature, starting from hunting, gathering, farming, to home industries; d) Dimensions of Local Resources. Every community will use local resources according to their needs and will not exploit them on a large scale or be commercialized. Society is required to balance the natural balance so that it does not have a harmful impact on it; e) Dimensions of Local Decision Making Mechanisms. Each community basically has its own local government or what is called a tribal government. A tribe is a legal entity that orders its citizens to act according to rules that have long been agreed upon. Then if someone violates these rules, then he will be given certain sanctions through the chief of the tribe as the decision maker; f) Dimensions of Local Group Solidarity. Humans are social creatures who need help from others in doing their jobs, because humans cannot live alone. Like humans work together in protecting the surrounding environment.

Sustainable tourism is often discussed and echoed by tourism experts around the world [9]. Application of the concept of sustainable tourism in the management and development of a tourism destination. UNWTO in [3] can be described as follows: 1) Natural, historical, cultural, and other resources for tourism are conserved for sustainable use in the future, and can provide benefits to the present community; 2) The development of tourism is planned and managed in such a way so that it does not cause serious environmental and socio-cultural problems in tourist areas; 3 ) The overall quality of the environment in the tourism area is maintained and improved where necessary; 4) High tourist satisfaction is maintained so that tourist destinations will still have their selling power and popularity; 5) The benefits of tourism are widespread throughout society.

Sustainable tourism management must pay attention to the following principles: a. Use renewable resources. b. Utilization for various purposes (multiple uses). c. Zone areas (designated / zoning). d. Conservation and preservation of resources (conservation and preservation of resources) [5]. 
The concept of rural tourism (rural tourism) with the characteristics of unique, distinctive and environmentally friendly products is likely to be a new solution for the development of tourism in the world [7]. As a response to the shift in tourist interest, Indonesia has also grown new tourist options in the form of tourist villages in various provinces in Indonesia.

\section{Methodology}

This research employs qualitative approach with a variety of ethnographic research tools for data collection. This type of research emphasizes the involvement of targets as active subjects, makes their experiences an integral part of research, finds problems, and is directed to solve problems by targeting empowerment.

Achieving the objectives of this study using participatory action research methods as a focus needs to be supported by other methods such as observation, in-depth interviews, focus group discussions (FGD). The informants in the study consisted of the main informants, namely the people of North Tugu Village who have lived in the village since childhood until now. The supporting informant is the head of the North Tugu village as the leader of the village government. The discussion process is carried out in a research process that focuses on finding elements of local wisdom as one of the important things to develop the sustainability of rural tourism.

The resource persons were the informants consisting of several groups, namely the village government, the Bogor Tourism Office, tourism activists, the people of Tugu Utara Village, and business actors in the area. This study describes the results of the findings obtained from informants, surveys, and conditions directly at the site.

Ethnography according to [2], from the science of tourism, can be used to explore community socio-cultural activities, certain rituals, language, beliefs, traditional ways of life and others, which can become a potential tourist attraction for later packaging. Interview data were analyzed and researched by means of gathering similar facts. Similar fact-gathering can be done referring to individual analysis or group analysis. If the analysis is individual, then the collection of similar facts follows the individual data, but if the data analysis is carried out using group or collective analysis, then the collection of similar facts is filled from all the data.

The research was conducted for 6 months to obtain data, data processing, and research publication. Conducted in Tugu Utara Village, Bogor Regency, directly involving the community and government in Tugu Utara Village. The research road map is as follows:

Fig. 2. Research Road Map

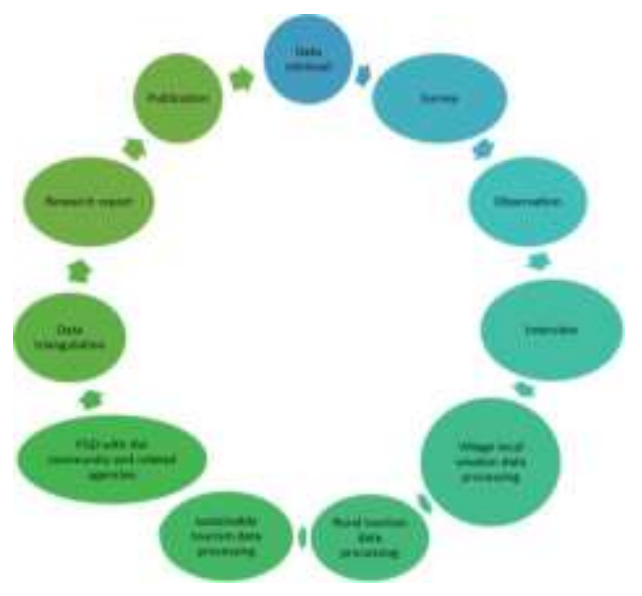




\section{Results and Discussion}

\subsection{Local Wisdom in Tugu Utara Village}

Local wisdom in the discussion of this research has six dimensions. The results of the research obtained indicate that the six dimensions have been built in the village of North Tugu.

\subsubsection{Local Knowledge Dimensions}

The people in Tugu Utara Village recognize the natural beauty in their village, the village potential, and the culture in the village. North Tugu Village has tourist destinations in the form of mountains, hills, waterfalls, lakes and lakes. However, there is a lack of understanding of the community in the management and development of their regional potential. This is due to education, public knowledge, and the lack of public awareness to take advantage of it together. The village already has a Pokdarwis named "Dewi Amarta". This group helps the role of the government, especially the village head, to carry out tourism activities and activate the community, as well as improve the economy of the surrounding community through tourism. The local knowledge that the North Tugu community has about the culture that must be preserved is still being applied.

\subsubsection{Local Value Dimensions}

Local values and collective agreements that are still upheld by the people of North Tugu Village are the culture of the greeting "punten". In everyday life, people want to be polite when they hang out, meet and visit, and stay in touch. Because this little thing has started to disappear in the millennial era, it can be seen from the habits of teenagers and adults who don't say the word "excuse me" when walking in front of other people. However, the people of Tugu Utara Village Bogor still apply this culture of courtesy.

\subsubsection{Local Skills Dimensions}

The people of Tugu Utara Village still have the ability to survive to fulfill their family needs. Judging from the results of research carried out directly, during the Covid 19 pandemic, people are still trying to survive to carry out activities that can improve the economy. The activities of farming and working as laborers in tea plantations are still being carried out, because the North Tugu Village area has a large tea garden. There are also people who work in coffee plantations, because the coffee harvested is sold directly in the area. Some people who work in the tourism industry carry out entrepreneurial activities. Some people sell cilok, gemplong cake, mix coffee into a drink served to migrants, and trade on the side of the road around the tea garden. The following describes the local skills possessed by the people of Tugu Utara Village.

The honey farming community in Tugu Utara Village produces Cerana and Mellifera honey types. The type of honey bee that is used produces high quality honey and lots of it. Besides producing honey, Mellifera honey bee cultivation in Tugu Utara Bogor also produces royal jelly and propolis. Cerana honey has a clear yellowish color, while Mellifera is brownish in color. This honey is sold in small bottles for IDR 100,000, large bottles, and sold using ready-to-consume bee hives. The price of this honey has reached millions of rupiah per bottle of syrup. The second image is a coffee plantation located in Cibulao Village in the North Tugu area. Coffee produced from plantations is Robusta coffee and Arabica coffee. 
Currently the coffee plantation is being prepared for coffee tourism, so that it can be used as a tourist destination in Tugu Utara Village, Bogor.

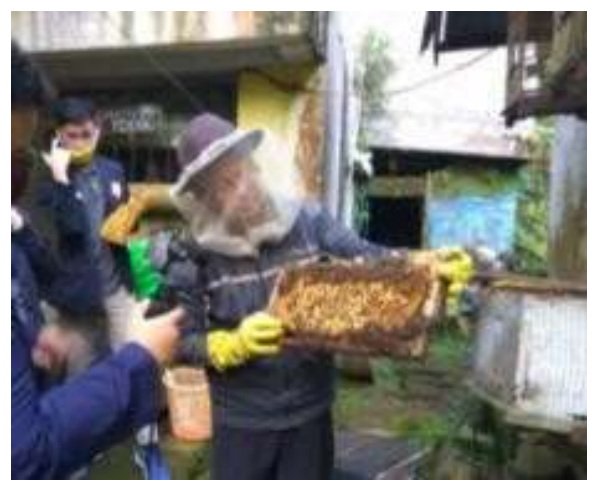

Fig. 3. Honey Farmers

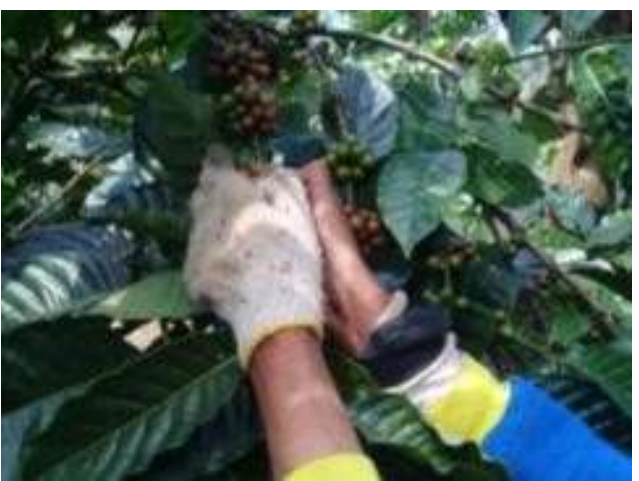

Fig. 4. Coffee Farmers

\subsubsection{Dimensions of Local Resources}

Every community will use local resources according to their needs and will not exploit on a large scale or be commercialized. The people of Tugu Utara Village still recognize the importance of using natural resources wisely. Even though there are some migrants who try to destroy the natural resources in the village, the community still maintains and looks after the village with hard efforts.

\subsubsection{Dimensions of Local Decision Making Mechanisms}

The people in Tugu Utara Village do not have ethnic and racial differences to make decisions. The head of the regional government, which is led by the Village Head (Mr. Asep Ma'Mun Nawawi), the community can consult with the Village Head for joint decision-making with the residents of Tugu Utara Village, Bogor.

\subsubsection{Dimensions of Local Group Solidarity}

The people of Tugu Utara Village, Bogor, have the "Dewi Amarta" community as Pokdarwis. The village also has a Karinding art community, a Silat Dodor silat (Cador) community, a kecapi suling community, an angklung community, and a reog art community (ketoprak). Each community in making decisions for each activity lies with the head of the studio, which is then discussed with the village head.

\subsection{Sustainable Tourism in Tugu Utara Village}

In this study, the use of sustainable tourism theory is based on references from UNWTO in [3]. The results of this study are based on the fact that Tugu Utara Village Bogor is divided into 12 elements of sustainable tourism, as follows:

\subsection{1 (EV) economic viability}

Based on the research results in terms of economic feasibility, most of the people in North Tugu Village have jobs as traders. The types of work in the area are traders, art actors, 
services (accommodation), coffee and tea farmers, honey cultivation, and offering villas in the top area of Bogor. In accordance with economic feasibility, it can be said that the village is able to build sustainable tourism.

\subsection{2 (LP) local prosperity}

Judging from the local prosperity, the community has abundant natural resources. There are several natural beauties that can be developed into tourist destinations. The area of Tugu Utara Village Bogor has Cisuren rock waterfall, Gunung Kencana, Batu Keraton, Telaga Saat, Citamiang, Cibulao Coffee, cultural arts, and handicrafts made by the community.
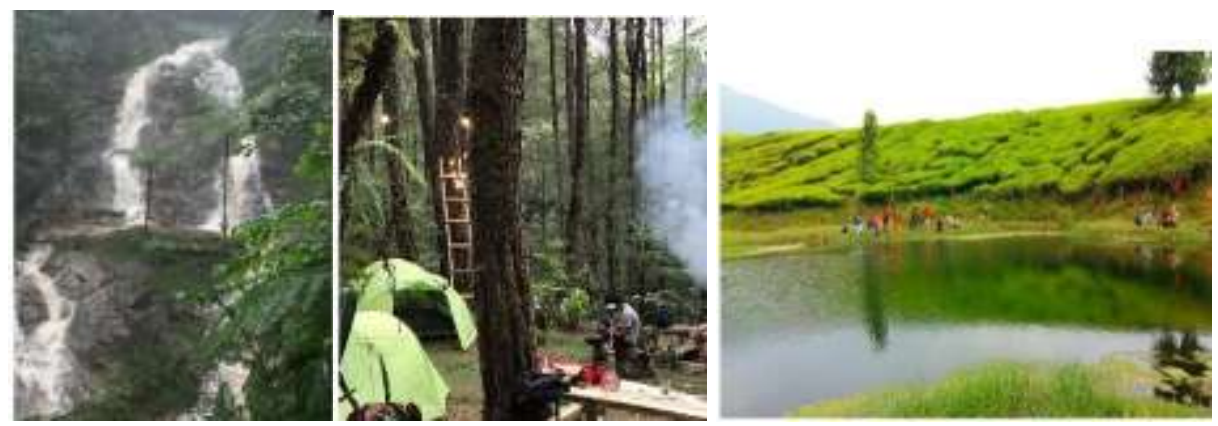

Fig. 5. Curug Batu Cisuren Picture, Cisuren Picture, Telaga Saat

\subsection{3 (VF) visitor fulfillment or visitor fulfillment}

Judging from the fulfillment of visitors, the residents of the capital are very familiar with the peak of Bogor. Without being heavily promoted, the visitors came to this area alone. However, this needs to be directed to Tugu Utara Village, Bogor. Because the Bogor area consists of several villages. The majority of visitors come to the top with the aim of tea gardens, safari parks, flower gardens, and waterfalls. So it is necessary to have an introduction and information, as well as a promotion of tourism in Tugu Utara Village, Bogor.

\subsection{4 (EQ) employment quality or quality of work}

Judging from the quality of work, Tugu Utara Village, Bogor, has various types of work. The activities held by the village community were classified as successful, because the cultural performances that were carried out went well and were able to make the surrounding community care and see them. Coffee farmer groups and the community hope that their harvest in Cibulao Village can be known to visitors and other communities. Now Cibulao coffee is a coffee center in Bogor, which is the goal of the Community-Based Farmers Group (KTBM) in Cibulao Village, Tugu Utara Village. The majority of community occupations are service workers, accommodation, tea farmers and coffee farmers.

\subsection{5 (SE) social equity or social justice}

In terms of social justice, the people in the village of Tugu Utara Bogor are trying to work together to build the village. Now the focus of the community is to jointly utilize natural resources to become the tourism sector. Because in this day and age, there are many tourism enthusiasts to fill their holiday time, boredom, and means of staying in touch. The village 
government also supports each other for tourism development activities in turns in the villages in the North Tugu area.

\subsection{6 (LC) local control or local control}

Local control is carried out by the community in Tugu Utara Village to achieve sustainability with the use of Sundanese in daily communication. The community still instills the value of mutual cooperation to help each other in village development.

\subsection{7 (CW) community wellbeing or community welfare}

In terms of community welfare, the village is classified as having a prosperous community, even though it is not from the upper middle class. However, people's creativity and motivation in creating art, trading, and creating activities to improve the community's economy.

\subsection{8 (CR) cultural rincheness or cultural acuity}

In terms of cultural acuity, the village of Tugu Utara, Bogor, still preserves artistic culture. There are kesenia reog (ketoprak), lute flute, silat (cador), karinding, donggrang, and traditional keris weapons.

\subsection{9 (PI) physical integrity}

The village community still applies physical integration as seen from their togetherness and integrity in village development efforts with the village government. There were deliberations to make activities in the village, try to find information, gain knowledge from the training activities that were followed, and welcome the arrival of academics to build the village of Tugu Utara Bogor.

\subsubsection{0 (BD) biological diversity or biodiversity}

The biodiversity of Tugu Utara Village Bogor consists of agricultural products, plantation products, and livestock. The village has tea plantations, coffee plantations that produce Robusta and Arabica coffee, Mellifera and Cerana honey cultivation. Vegetable agricultural products are usually traded along the Bogor summit road, the direction to enter the Safari park, and souvenirs. The area has taro, Cilembu sweet potato, strawberries, cassava, spinach and various processed bananas.

\subsubsection{2 (RE) resource efficiency}

In terms of resource efficiency, the people of Tugu Utara Village are using their resources well. People who are developing tourism in the village of Tugu Utara Bogor still pay attention to the beauty of the environment and do not destroy nature. Pokdarwis Dewi Amarta and the people who care about it and take care of it.

\subsubsection{3 (EP) environmental purity or environmental purity}

Judging from the purity of the environment, Desa Tugu Utara Bogor has a beautiful, pure, and not much contaminated environment. The sustainability of village development is still 
directed at utilizing natural resources and maintaining the natural beauty of the village. This area is surrounded by mountains, hills, has many waterfalls, rivers, plantations, agriculture, ponds, and growing trees.

Based on research result [4], local Wisdoms were used to teaching and learning material and facilitate learning trigger. There were 7 local wisdoms can be used as the teaching and learning material, namely Syukuran Panen, Tajin Sappar, Can Macanan Kadduk, Pelet Kandhung, Gotong Royong, Respecting Kyai, Musyawarah. The other 7 local wisdoms were used to facilitate learning trigger, namely Diba'an, Manaqiban, Yasinan, Hadrah, Pengajian, Sholawatan, Tahlilan.

This research is in line with this research, because it uses indicators of local culture in the research. That there are 7 local cultures contained in the research.

\subsection{Development of sustainable rural tourism through local wisdom}

Based on the results of research and classification of local wisdom and sustainable tourism, Tugu Utara Village Bogor can be developed into sustainable rural tourism. The local wisdom possessed by the village community and the authenticity of the culture in the village Local wisdom that is owned by the village community and the authenticity of the culture in the village is a sustainable tourism village development. There needs to be assistance, training and knowledge from experts to support tourism development.

Natural resources in the village of Tugu Utara Bogor are the main things that can be used for the development of rural tourism. The local culture that is still preserved, community cooperation, and the desire of the community in advancing the village are the basis for the development of sustainable tourism.

The socio-economic quality of rural communities in tourism development has a positive impact (benefits) on the local community's socio-economy, such as growing job opportunities, or even making it an economically independent community. This has been implemented in Tugu Utara Village. The community and Pokdarwis Dewi Amarta and the Village Head took turns making efforts to build community independence in improving the economy through service and tourism businesses.

Tourism development must be sensitive to the level of tourist satisfaction, so that making the tour as a valuable experience. In this case, the quality of tourism products and their interpretation has a very important role for the quality of one's travel experience. The hospitality of the community in entertaining visitors is a hallmark of the village of Tugu Utara Bogor.

\section{Conclusion}

All the research results that have been carried out in the village of Tugu Utara Bogor regarding local wisdom of sustainable tourism village development. Based on the results of research in the development of sustainable tourism studied in Tugu Utara Village, Bogor, West Java, that: local culture is still being developed in the village of North Tugu Village in the form of language, manners, and a spirit of mutual cooperation. This research achieved results in the form of local culture that is still maintained in the village of North Tugu. Now the people of North Tugu village are getting stronger in carrying out local culture, such as training to play angklung, displaying angklung at the tourist location of North Tugu village, namely Telaga Saat. The existence of research activities and direct interaction with the community, makes people aware and remember the culture they have. So that it is further preserved and introduced to their children. 


\section{References}

1. Humaida, Nida, Ese International Journal, 12 (2018)

2. Hermawan, $\mathrm{H}$, Metode Kualitatif untuk Riset Pariwisata. https://doi.org/10.31227/osf.io/nyvug. (2018).

3. Koesnadi Hardjasoemantri, Hukum Tata Lingkungan. Yogyakarta: Gajah Mada University Press, (2002)

4. Laksono, Bayu Adi, et.al, PEOPLE: International Journal of Social Sciences, 42, 13201336 (2018)

5. Pitana, I Gde dan I Ketut Surya Diarta. Pengantar Ilmu Pariwisata. Jogyakarta: ANDI. (2009)

6. Rustiadi, Ernan. http://fwi.or.id/publikasi/bergerak-dari-hulu-bersama- menyelamatkanpuncak/. Downloaded 1 July 2020. At 01.20 a.m. (2016).

7. Susyanti, Dewi Winarni, Jurnal Ekonomi dan Bisnis, 121, 33-36, http://jurnal.pnj.ac.id/index.php/ekbis/article/view/650/pdf_45. (2013)

8. Suparmini, dkk, Jurnal Penelitian Humaniora, 181, 8-22 (2013) https://journal.uny.ac.id/index.php/humaniora/article/view/3180/2665.

9. Sulistyadi, Yohanes. Pariwisata Berkelanjutan dalam Perspektif Pariwisata Budaya di Taman Hutan Raya Banten. Cet.1. Ponorogo: Uwais Inspirasi Indonesia. (2019).

10. https://kecamatancisarua.bogorkab.go.id/pages/1749. Downloaded at 1 July 2020. 